\title{
Correction to: A collaborative care psychosocial intervention to improve late life depression in socioeconomically deprived areas of Guarulhos, Brazil: the PROACTIVE cluster randomised controlled trial protocol
}

\author{
Marcia Scazufca ${ }^{1 * \dagger}$, Carina Akemi Nakamura ${ }^{2 \dagger}$, Tim J. Peters ${ }^{3}$, Maiara Garcia Henrique ${ }^{2}$, Antônio Seabra ${ }^{4}$, \\ Ehidee Gomez La Rotta ${ }^{2}$, Renato M. Franzin ${ }^{4}$, Daniele Ferreira Martins ${ }^{2}$, Pepijn Van de Ven ${ }^{5}$, \\ William Hollingworth ${ }^{3}$ and Ricardo Araya ${ }^{6^{*}}$
}

\section{Correction to: Trials 21, 914 (2020) \\ http://orcid.org/10.1186/s13063-020-04826-w}

Following publication of the original article [1], we were notified that the academic title for two of the authors, as well as the affiliation of Pepijn Van den Ven need to be corrected.

- Originally published academic titles:

Paula Verônica Martini Maciel, D.D.D.

Walter Freitas Junior, M.D.

- Correct academic titles:

Paula Verônica Martini Maciel, M.D.

Walter Freitas Junior, D.D.D.
- Original affiliation:

Faculty of Science and Engeneering, University of Limerick, Limerick, England

- Corrected affiliation:

Health Research Institute, University of Limerick, Limerick, Ireland

The original article has been corrected.

The original article can be found online at https://doi.org/10.1186/s13063020-04826-W.

*Correspondence: scazufca@usp.br; ricardo.araya@kcl.ac.uk

${ }^{\dagger}$ Marcia Scazufca and Carina Akemi Nakamura contributed equally to this work.

${ }^{1}$ Hospital das Clinicas HCFMUSP, Faculdade de Medicina, Universidade de Sao Paulo, Sao Paulo, Brazil

${ }^{6}$ Institute of Psychiatry, Psychology and Neurosciences, King's College London, London, England

Full list of author information is available at the end of the article

(c) The Author(s). 2020 Open Access This article is licensed under a Creative Commons Attribution 4.0 International License, which permits use, sharing, adaptation, distribution and reproduction in any medium or format, as long as you give appropriate credit to the original author(s) and the source, provide a link to the Creative Commons licence, and indicate if changes were made. The images or other third party material in this article are included in the article's Creative Commons licence, unless indicated otherwise in a credit line to the material. If material is not included in the article's Creative Commons licence and your intended use is not permitted by statutory regulation or exceeds the permitted use, you will need to obtain permission directly from the copyright holder. To view a copy of this licence, visit http://creativecommons.org/licenses/by/4.0/ The Creative Commons Public Domain Dedication waiver (http://creativecommons.org/publicdomain/zero/1.0/) applies to the data made available in this article, unless otherwise stated in a credit line to the data. 


\section{Author details}

${ }^{1}$ Hospital das Clinicas HCFMUSP, Faculdade de Medicina, Universidade de Sao Paulo, Sao Paulo, Brazil. ${ }^{2}$ Faculdade de Medicina FMUSP, Universidade de Sao Paulo, Sao Paulo, Brazil. ${ }^{3}$ University of Bristol Medical School, Bristol, England. ${ }^{4}$ Departamento de Engenharia Eletrica, Escola Politecnica, Universidade de Sao Paulo, Sao Paulo, Brazil. ${ }^{5}$ Health Research Institute, University of Limerick, Limerick, Ireland. Institute of Psychiatry, Psychology and Neurosciences, King's College London, London, England.

Published online: 16 December 2020

\section{Reference}

1. Scazufca, et al. A collaborative care psychosocial intervention to improve late life depression in socioeconomically deprived areas of Guarulhos, Brazil: the PROACTIVE cluster randomised controlled trial protocol. Trials. 2020;21:914. https://doi.org/10.1186/s13063-020-04826. 